J. Environ. Sci.

Institute of Environmental Studies and Research - Ain Shams University

\title{
THE USE OF GIS TO VERIFY SOCIAL JUSTICE IN DISTRIBUTING EDUCATIONAL SERVICES IN MANSOURA CITY
}

\begin{abstract}
Ahmed Gh. Ibrahim ${ }^{(1)}$; Bashaier E. M. Khairy ${ }^{(2)}$ and Hala A. Effat ${ }^{(3)}$ 1) Post graduate. Institute of Environmental Studies and Research, Ain Shams University 2) Faculty of Engineering, Ain Shams University 3) National Authority for Remote Sensing and Space Sciences
\end{abstract}

\begin{abstract}
This paper aims to assist the availability of educational buildings in Mansoura city. Being a community lying in the middle of the Nile delta with no desert extension; it is necessary facilitate the best use for the existing vacant land to prevent the dredging of the surrounding agricultural land. The assessment process is based on the database of the strategic plan for the city; this database is processed using the ArcGIS 10.4.1 software to perform the suggested methodology for studying the present situation. This methodology depends on using the spatial analysis tools in the software used, applying parameters mentioned in the guidelines and standards for a service regarding its effective zone. Results reveal a shortage of abundance in the educational service in the city, so the proposal of the location of the new services location is done also applying the same parameters mentioned previously. The proposed new locations are abiding the directory of distribution of land use activities in Egyptian cities, to determine the type of land use, permitted in each zone of the city according to the nature of such zone.
\end{abstract}

Keywords: GIS, Spatial analysis, Educational service, Land-use, Service effect zone.

\section{INTRODUCTION}

Geographic information system (GIS) is rapidly being developed and applied in a no-limit list of applications. Planning in particular, have greatly 
benefited from this effective and efficient technology (Antenucci J., Brown K., Croswell P. Kevany M., with Archer H., 1991). GIS is used today in several planning applications including land use planning, health care planning and transportation planning. (Jamal Mohamadi, Mohamad Rasoli, Hasel Dastineh and Faryad Parhiz; 2014) used GIS techniques to produce maps for the spatial distribution for urban services at urban neighborhood level in the city of Prianshahr as it has a comprehensive plan in order to actualize the social justice. The study revealed a dissatisfaction of the urban service distribution. (Gomma M. Dawod, Meraj N. Mirza, Ramze A. Elzahrany, Khalid A. Al-Ghamdi; 2013) used GIS spatial analysis to investigate the spatial distribution of education, health, security, religion, commercial and sports services over the municipal election areas within Mekkah city. The GIS analysis showed that except for the religion services all the services are not quantitatively proportioned with the population variation in the city. (Waleed Lagrab, Noura Aknin, 2015) conducted a study using the GIS on the kindergarten in Mukalla district in Yeman. The authors pointed out the strength and weakness of the existing distribution and proposed the solutions to help the decision makers in order not to fall in the same mistakes once more while allocating the future locations for this service. (Mazloh AlEnazi, Saleh Mesbah, Amani Anwar, 2016) used GIS functions to analyze the database for the city of Jeddah in order to evaluate the spatial distribution of the schools to help the planners to manage the future distribution of schools in the city. (Noor Hashim Hameed, 2016) conducted a study on the accessibility indicators for primary schools in the most residential sectors of Karbala city. The study concluded that: the indicatorswere not achieved; using the GIS 
abilities to solve the numerous geographic problems.

The education sector in Egypt the main objective of the current study as in many other third world countries, is faced with multi problems such as the lack of human resource, infrastructure imbalance between demand and supply. The GIS is the one of the most powerful tools to help the decision makers to manipulate the available resources in order to achieve the social justice in the educational services in the urban areas. Using the spatial analysis tools found in the software.

In this paper the target is to study the fair distribution of the primary schools in the Mansoura city the main city in the Dakahleyia governorate which is one of the main governorates in the Egyptian delta region as shown in Figure(1). The equitability of the distribution of the service in the city prevents the illegal dredging agricultural land surrounding all the cities in the Nile delta governorates which have no desert extension as shown in Figure (2). 


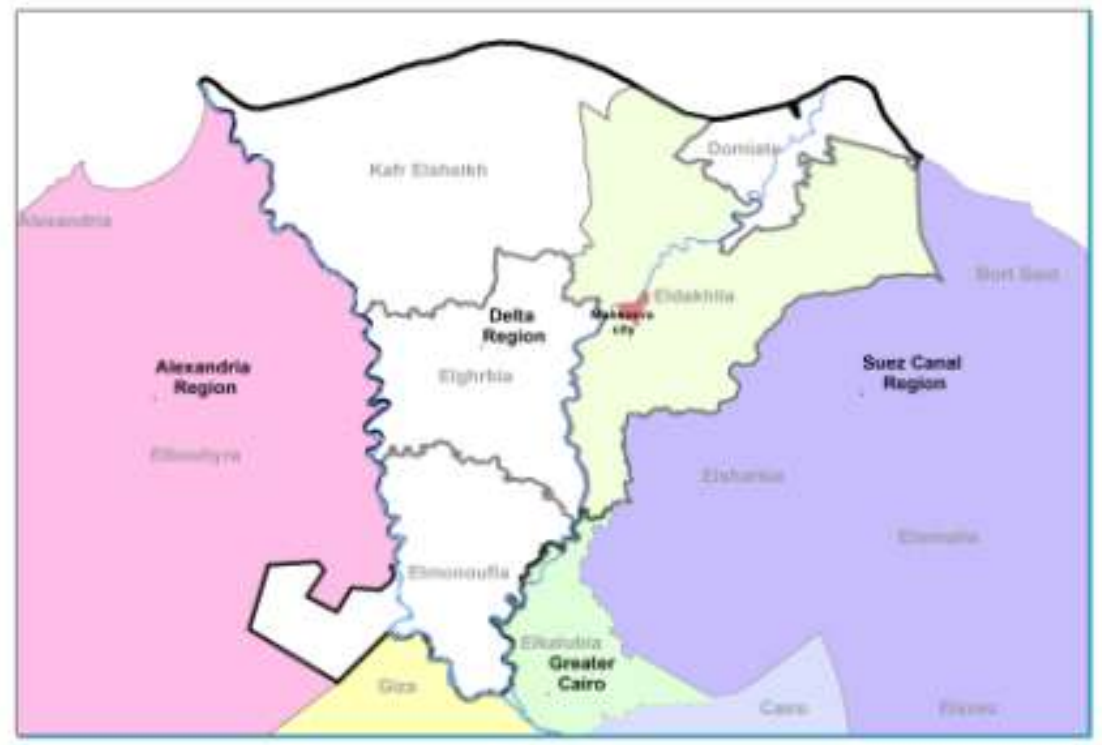

Figure (1): Location of El-Mansoura city

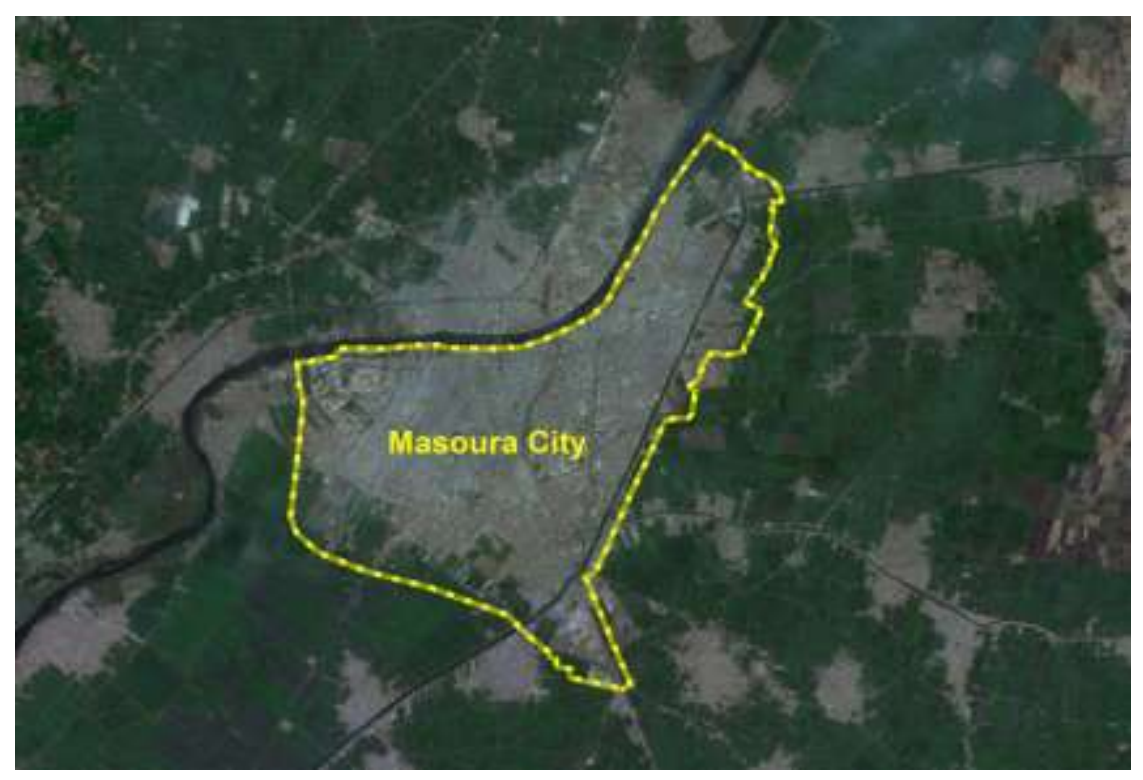

Figure (2): Mansoura city urban boundary and agricultural land around it 


\section{Materials:}

The study analyzes and assesses the database of the city created by the General Organization of Physical Planning in 2008 and is updated by the author using high resolution images in 2017 for the El-Mansura city present situation; also presents the extensions of the city strategic plan.

\section{Methods:}

1. The database layer for city buildings was used. The primary school buildings were selected and extracted to a separate layer.

2. The city administrative divisions (Sheyakha) were used as the unit of comparison. The number of schools in each division was added in a separate field.

3. The terms of references for the school distribution (General Organization for Physical Planning, 2014: The guidelines and standards for educational service) was reviewed and a threshold was used to create a buffer zone around each school as the sphere of influence for the service provision of such schools.

4. The Euclidian distance module was applied using Esri spatial analysis ArcGIS 10.4.1 software to analyze the distribution of school units, sphere of influence and the covered zones.

\section{RESULTS AND DISCUSSION}

The city database reveals` that the primary schools are distributed in the city divisions (sheyakhas) as shown in the following Figure (3). 


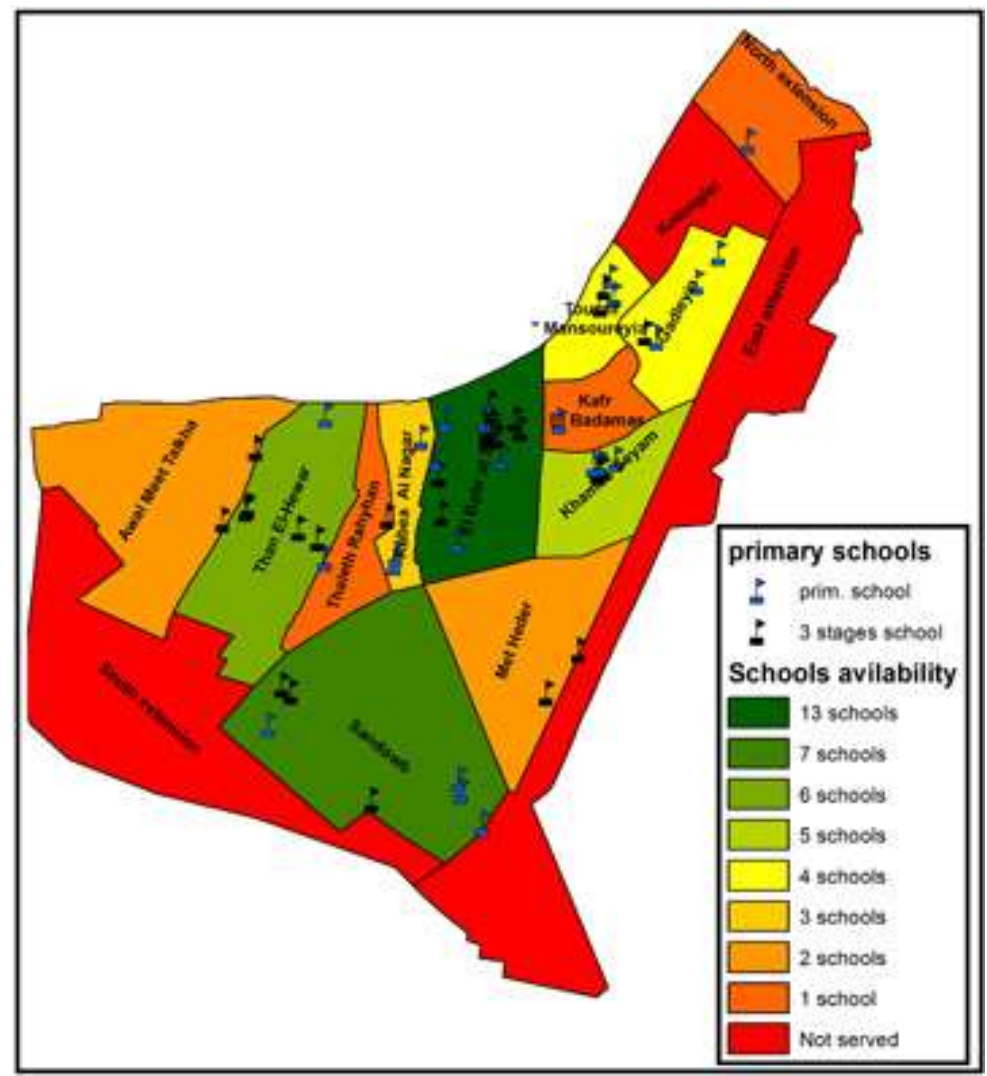

Figure (3): Abundance and spatial distribution of schools in El-Mansoura city districts (Sheyakha)

Accordingly it is clear that there are some areas in the existing city bulk or future extension deprived of the educational service after applying the spatial location analysis for the existing schools mentioned in the terms of references for the school distribution (The General Organization for Physical Planning (2014). The guidelines and standards for educational service); states that the 
travel distance for the primary stage students should range from $500-750$ meters as shown Figure (4).
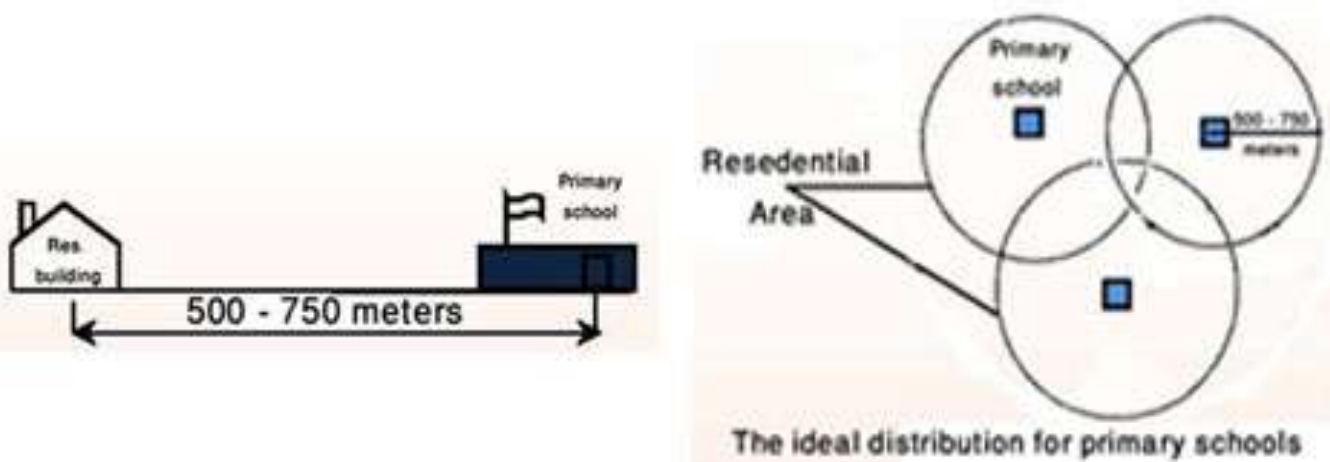

Figure (4): The ideal distribution for primary schools. The guidelines and standards for educational service

Applying the travel distance parameter using the spatial analysis tools found in the ArcGIS 10.4.1 software reveals that the state of the city regarding the primary schools availability does not cover the investigated area. Some zones are far from schools by a distance that exceed the threshold 750 meters as shown in Figure (5).

Analyzing the database of the city, it was found that there are sufficient vacant lands inside the existing city bulk or in the city extension. Twelve new locations for primary schools were proposed based on the study results. These locations are meant to fulfill the city needs for the year 2027 (the target year in the city strategic plane). The same procedure is done on the proposed locations reaching the result shown in Figure (6). 


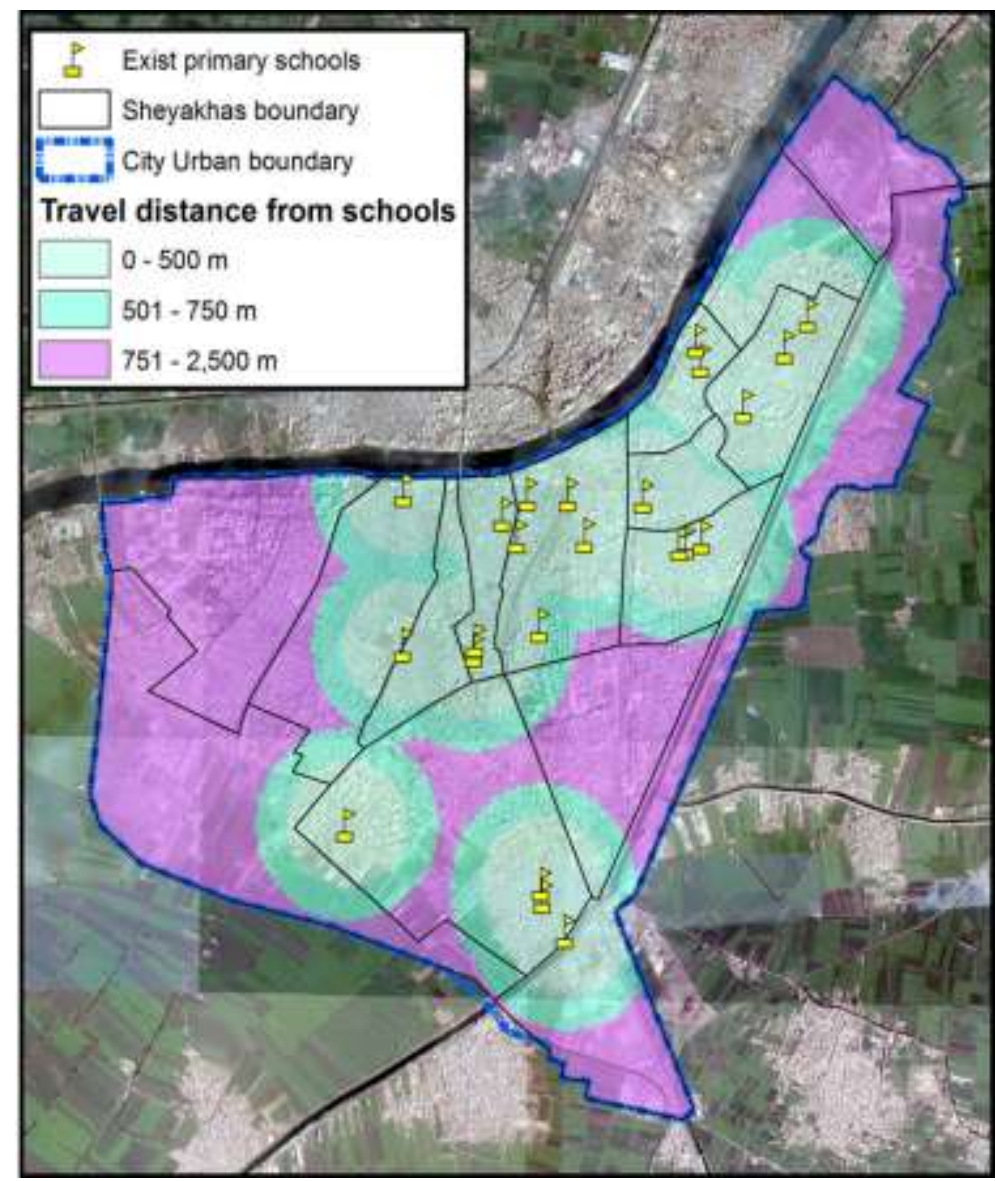

Figure (5): Distance thresholds and spheres of influence of existing schools in El-Manousra city 


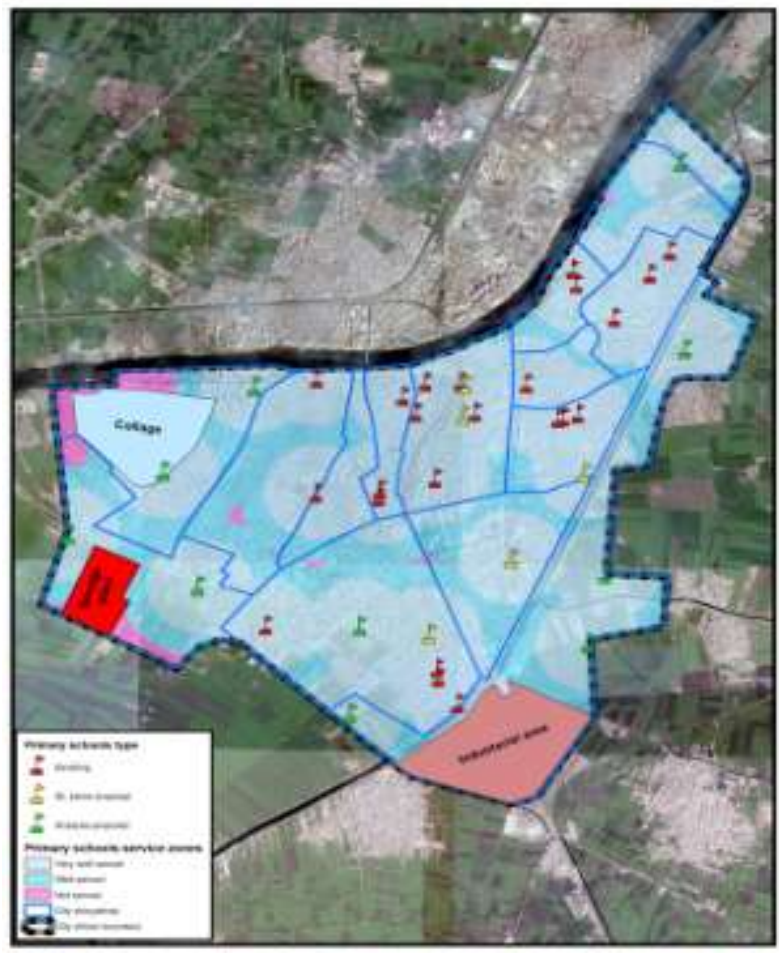

Figure (6): Map showing the distribution of existing schools (red), proposed schools (yellow) and schools proposed based on the study (green).

This shows that the primary schools service is fairly distributed among the city which fulfills the need for such service.

All the proposed locations are assessed regarding three main points which are:

\section{The existing land- use}

All the locations proposed in this study are chosen on a vacant land parcels according to the city database; also allocated on locations compatible with the Egyptian standards (The General Organization for Physical Planning 
(2016): The directory of distribution of land use activities in Egyptian cities). As shown in the following Figure (7).

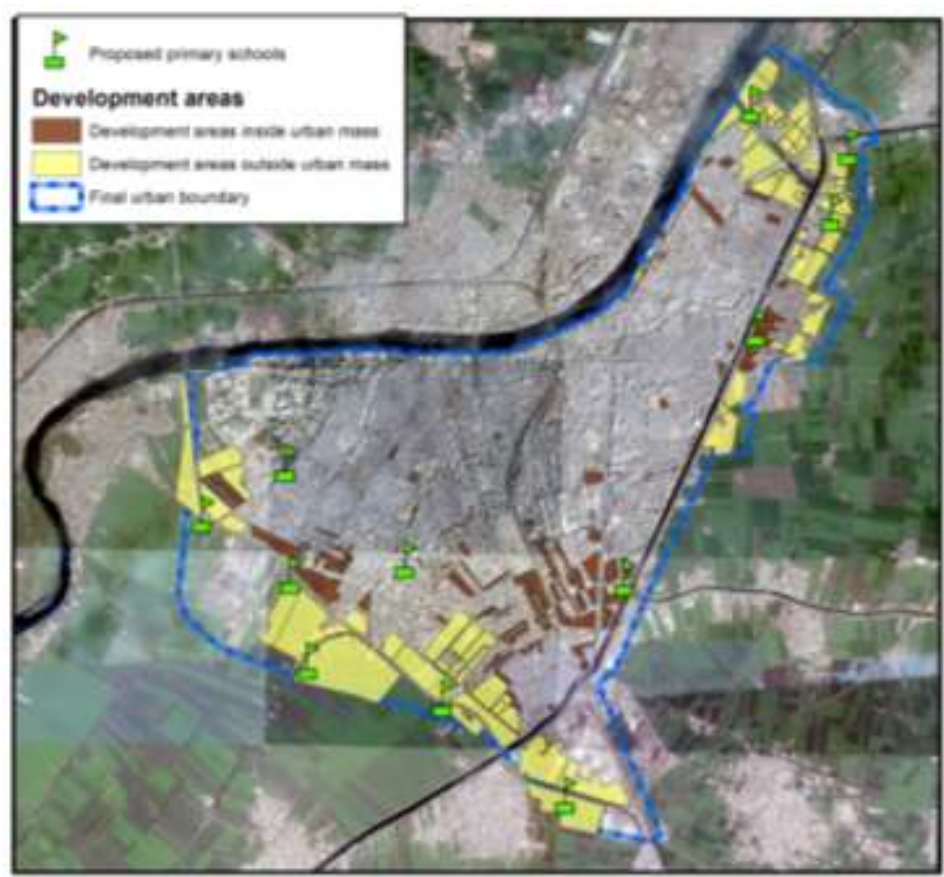

Figure (7): Development areas inside urban mass (brown) in the city extension (yellow).

\section{Assessment of the distance from Noise and Pollution.}

The main source of noise pollution in the city is the handcraft workshops. Air pollution is produced mainly by garbage collection points. The study considered a safety distance from noise and pollution sources. All school locations proposed in the current study are allocated far from such sources to avoid health problems and negative environmental impacts Figure (8).

\section{Assessment of the Accessibility}

According to the Egyptian standards for utility allocation for educational service buildings, both have to be allocating in site oriented on 26

Vol. 47, No. 1, Spt. 2019 
J. Environ. Sci.

Institute of Environmental Studies and Research - Ain Shams University

main or sub main roads. This factor was followed in the selection of the new locations Figure (9).

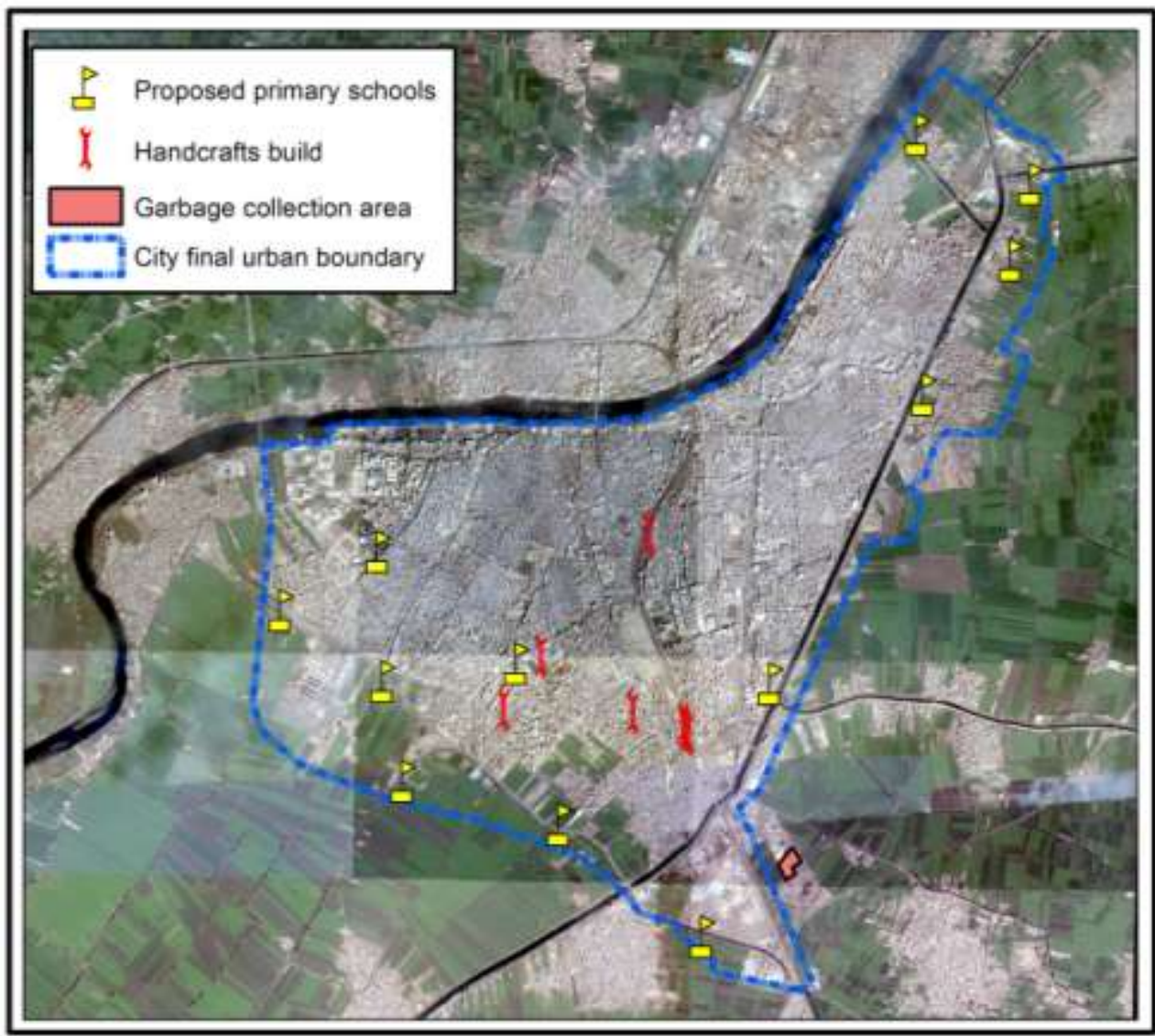

Figure (8): Location of the proposed school locations versus the garbage collection site. 


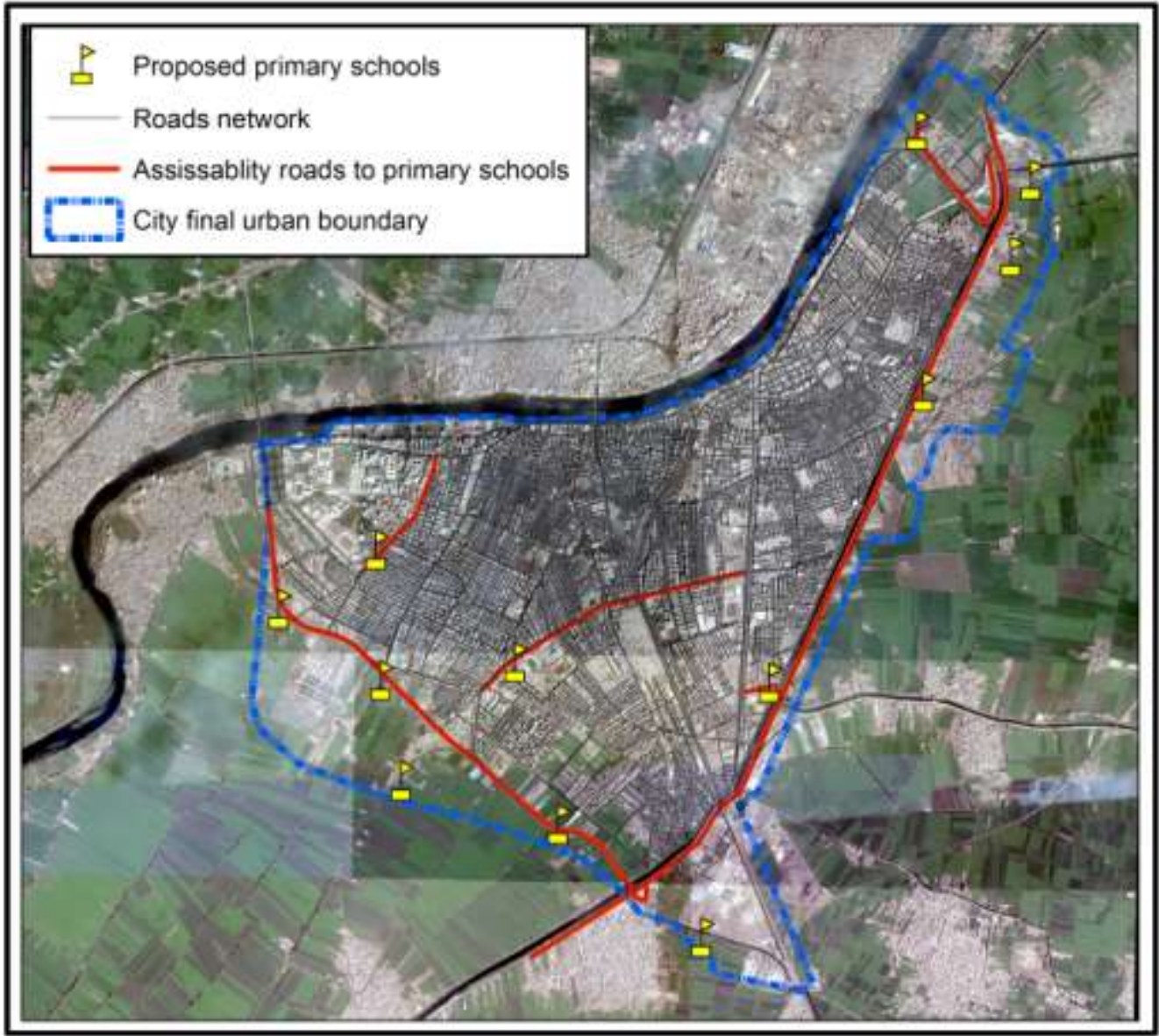

Figure (9): Accessibility of the proposed locations for new school 
J. Environ. Sci.

Institute of Environmental Studies and Research - Ain Shams University

\section{CONCLUSION}

Despite all the efforts done by the Egyptian governorate to ensure good planning for cities and to reach a fair distribution of general services. More efforts need to be conducted in the allocation of primary schools in Mansoura city.

The use of geographic information systems revealed the real situation in the city. Spatial analysis provided solutions for site selections and allocations that comply with the national and (or) international standards.

\section{RECOMMENDATIONS}

- All the added areas to the existing city urban boundary must be named in order to facilitate the analysis process for its needs.

- Most of the land parcels inside El-Mansoura city and in the surrounding areas are private properties. A fair methodology for land screening and assessment is needed to allocate the services needed by the city.

- In the stage of service state evaluation to calculate the city needs in the city current situation or in the in the proposal stage the study must take in consideration the spatial location factor, which divides the city into two types served area and un-served area; the study has to assess the standards determining the travel distance and sphere of influence to be covered to reach the service. This factor is well defined in the guidelines and standards for each services type published by the General Organization for Physical Planning.

- It is recommended to suspend the approvals made by the Educational Buildings Authority for the establishment of the schools of the agricultural 
lands outside the urban areas, which compelled the Ministry of Agriculture previously to approve the establishment of the school on agricultural land.

- The use of all the capabilities of the Geographic Information System (GIS) in the urban planning is highly recommended. As the use of such technology is quite limited in most developing countries.

- It is recommended to use the spatial analysis capabilities in this software in land-use decision making and urban planning.

\section{REFERENCES}

Antenucci J., Brown K., Croswell P. Kevany M., with Archer H., (1991) Geographic Information System: A Guide to the Technology.

General Organization for Physical Planning (2014): The guidelines and standards for educational service.

General Organization for Physical Planning (2016): The directory of distribution of land use activities in Egyptian cities.

Gomaa M. Dawod, Meraj N. Mirza, Ramze A. Elzahrany, Khalid A. AlGhamdi, 2013, GIS-Based Public Services Analysis Based on Municipal Election Areas: A Methodological Approach for the City of Makkah, Saudi Arabia Journal of Geographic Information System, 5, 378-395.

Jamal Mohamadi, Mohamad Rasoli, Hasel Dastineh and Faryad Parhiz; 2014, Analysis of the Services Spatial Distribution in the Urban Areas (Piranshahr City as a Case Study), Journal of Sociological Research, Vol. 5, No.1.

Mazloh Al-Enazi, Saleh Mesbah, Amani Anwar; 2016, Schools Distribution Planning using GIS in Jeddah City, International Journal of Computer Applications Volume 138 - No.1.

Noor Hashim Hameed, 2016 On the use of GIS Technique to Analyze the Distribution of Primary Schools in Holy Karbala City, Eng. \&Tech. Jounal, Vol.34, Part (A), No.15, 2016. 
Waleed Lagrab, Noura Aknin; 2015, Analysis Of Educational Services Distribution-Based Geographic Information System (GIS) International journal of scientific and technology research Volume 4, Issue 03.

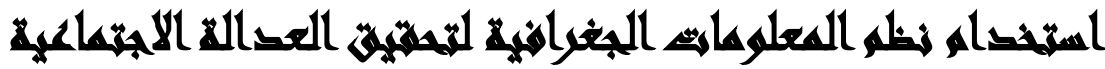

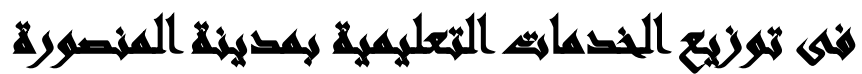

\section{$[r]$}

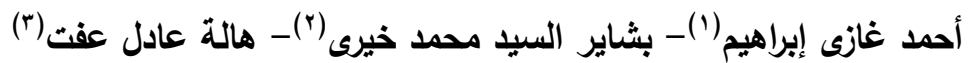

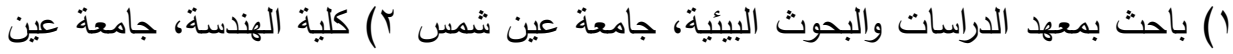
شمس r) الهيئة القومية للاستشعار من البعد وعلوم الفضاء.

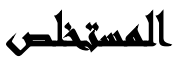

يعتبر التعليم من أهم متطلبات العصر الحديث لما له من دور هام فى التقدم والنهوض بالأمم؛

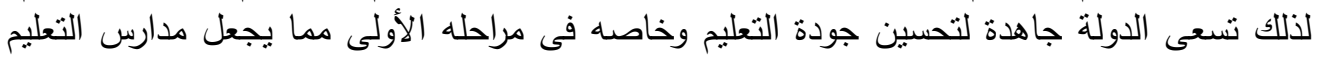

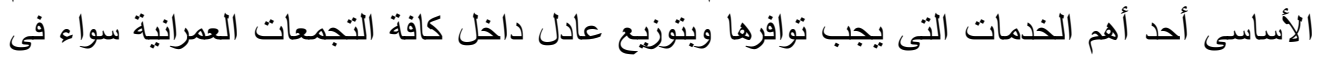

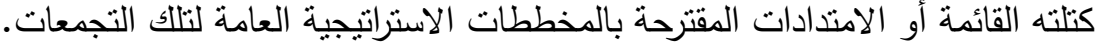

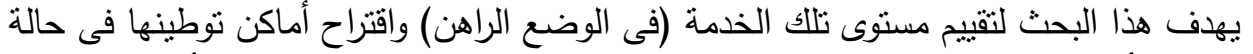

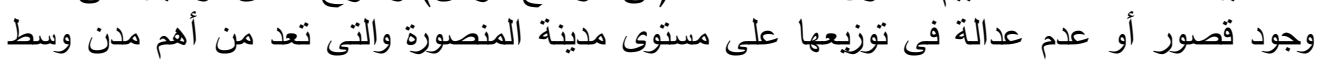

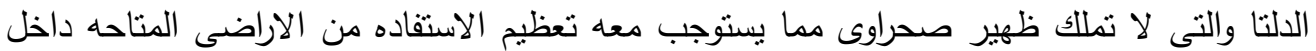
الكتله العمرانية للحفاظ على الرقعة الزراعية من حولها.

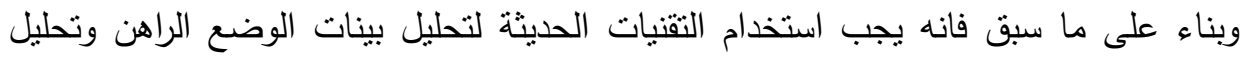

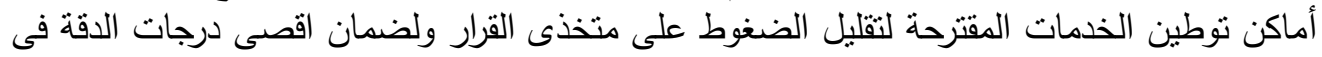

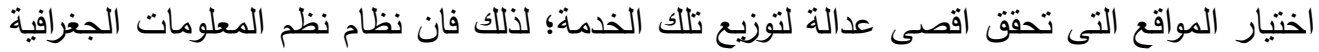

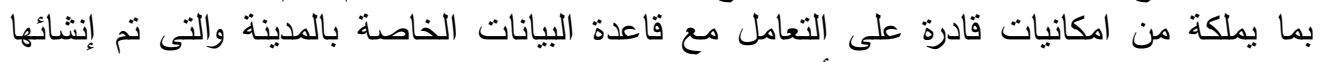

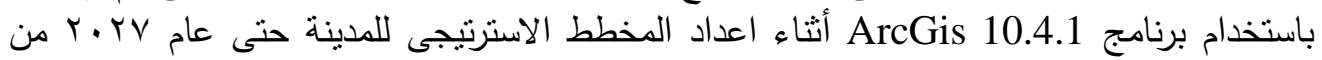
قبل الهيئة العامة للتخطيط العمرانى.

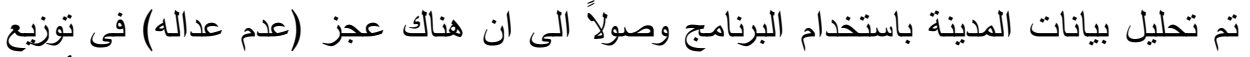

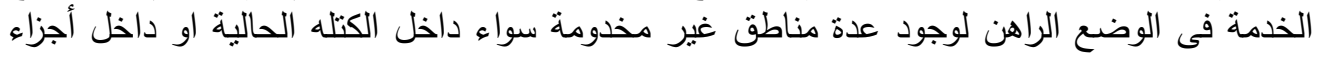

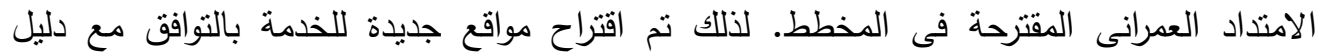
المعدلات والمعايير التخطيطية للخدمة فى جمهورية مصر العربية لتوطين الخدمات والمعد من قبل فيل 
الهئية العامة للتخطيط العمارنى (الجهه المسئولة عن التخطيط العمرانى بجمهورية مصر العربية وفقاً

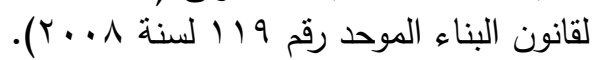

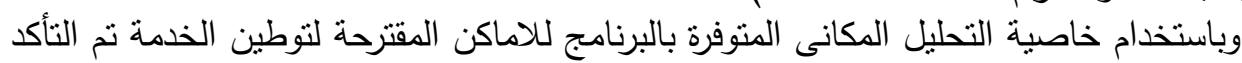

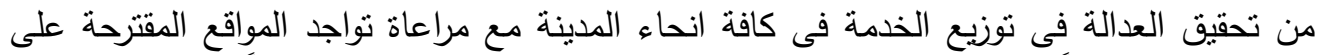

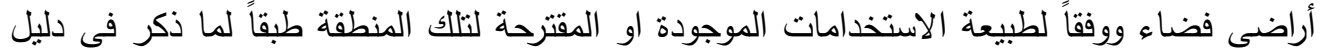

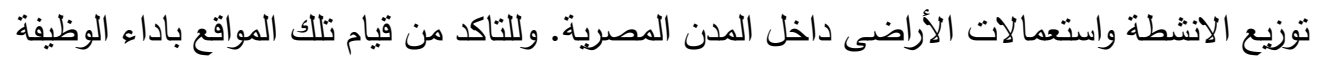

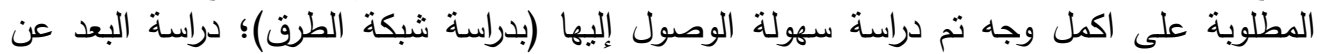
مصادر تلوث الهواء والضوضاء. 